IRA-International Journal of Management \& Social Sciences

ISSN 2455-2267; Vol.09, Issue 01 (October 2017)

Pg. no. 27-37

Institute of Research Advances

http://research-advances.org/index.php/RAJMSS

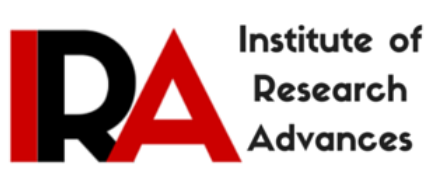

\title{
Effect of Composite Stock Price Index, Exchange Rate and Interest Rate Share Price of Mining Companies Listed in Indonesia Stock Exchange
}

\author{
Imaduddin Murdifin $^{1}$ \& Suriyanti Andi Mangkona ${ }^{2}$ \\ ${ }^{1,2}$ Associate Professor of Management Science in University of Muslim Indonesia, Indonesia.
}

Type of Review: Peer Reviewed.

DOI: http://dx.doi.org/10.21013/jmss.v9.v1.p4

How to cite this paper:
Murdifin, I., Mangkona, S.A. (2017). Effect of Composite Stock Price Index, Exchange Rate and Interest
Rate Share Price of Mining Companies Listed in Indonesia Stock Exchange. IRA-International Journal of
Management \& Social Sciences (ISSN 2455-2267), 9(1), 27-37. doi:http://dx.doi.org/10.21013/jmss.v9.n1.p4

(C) Institute of Research Advances.

\section{(cc) BY-no}

This work is licensed under a Creative Commons Attribution-Non Commercial 4.0 International License subject to proper citation to the publication source of the work.

Disclaimer: The scholarly papers as reviewed and published by the Institute of Research Advances (IRA) are the views and opinions of their respective authors and are not the views or opinions of the IRA. The IRA disclaims of any harm or loss caused due to the published content to any party.

Institute of Research Advances is an institutional publisher member of Publishers Inter Linking Association Inc. (PILA-CrossRef), USA. The institute is an institutional signatory to the Budapest Open Access Initiative, Hungary advocating the open access of scientific and scholarly knowledge. The Institute is a registered content provider under Open Access Initiative Protocol for Metadata Harvesting (OAI-PMH).

The journal is indexed \& included in WorldCat Discovery Service (USA), CrossRef Metadata Search (USA), WorldCat (USA), OCLC (USA), Open J-Gate (India), EZB (Germany) Scilit (Switzerland), Airiti (China), Bielefeld Academic Search Engine (BASE) of Bielefeld University, Germany, PKP Index of Simon Fraser University, Canada. 


\begin{abstract}
This study aimed to examine the effect of Composite Stock Price Index (Composite Stock Price Index (CSPI)), the exchange rate, and interest rates on stock prices of mining companies listed in Indonesia stock Exchange. This research is associative with quantitative approach. Data were analyzed using panel data regression. The data used is secondary data such as financial data, and the percentage of monthly interest rates over the last three years. The collection of data taken with documentation techniques derived from published reports of Bank Indonesia and the Indonesia Stock Exchange. Sampling was done by purposive sampling with the number nine companies. The results showed that the CSPI and interest rates but not significant positive effect on stock prices. The rupiah exchange rate and significant negative effect on stock prices. Simultaneously the composite stock price index, the rupiah exchange rate, and interest rates have a significant effect on stock prices of mining companies listed on the Indonesia Stock Exchange.
\end{abstract}

Keywords: Stock price, CSPI, exchange rates value, SBI, interest rates

\title{
Introduction
}

The development of industry and technology very rapidly lead to the stock market into most aspects received much attention throughout the country. As a result shift or capital flight abroad to be quite rapid. This is the impact of the falling value of the rupiah or high inflation and low interest rates in a country. In addition, due to the absence of alternative profitable investments in the country, or at the same time the portfolio investment in the stock of other countries promising a much higher profit. This occurs as a consequence of the opening of the stock market to foreign investors.

One of the sectors in Indonesia Stock Exchange is the mining sector, where this sector is one of the leading sectors of interest to investors. This is consistent with Imawan statement as a Chairman of the Indonesian Mining Services Association (Aspindo) where significant growth of the mining industry in the past two decades, as seen from the contribution of revenues from this sector. Moreover, he added the important role of Indonesia's mining industry growth can be seen from the national mine production, such as coal, tin, nickel, copper, and gold were excellent. However, related to national coal production he has contributed significantly mining services company. This indirectly increases gradually mining company's stock price that had dropped drastically in 2008 due to the global economic crisis.

Capital market developments can be shown by changes in price and volume of shares traded stock trading itself. The movement of stock prices may provide clues about the increase and decrease in capital market activity and investors in buying or selling stocks. More specifically, one aspect of which is most often the subject of conversation is pricing issues shares in the capital market trading. The whole basic concept of evaluation of the stock price is based on the belief that all of the equity securities have intrinsic value which is the value of an asset that is contained in a particular investor and the value of thinking is justified by the facts and may differ from the current market price of assets. By knowing the intrinsic value as the theoretical price of a stock that will provide answers to investors about what can be purchased in a way that should determine the price of a stock. So that an investor would be buying a stock that does not exceed the market price of its intrinsic value (Husnan, 2005).

Very important business development activities of the company in the face of the business world are increasingly keen competition. Since July 1997 the rupiah exchange rate against the dollar continues to flare up. The volatility of the rupiah so high is bad for the world and the country's economy. The rupiah exchange rate volatility triggers coming from the supply side and demand. Thus logically high value of the rupiah exchange rate will have a positive impact on stock prices.

The interest rate is the amount of money paid in return for the use of the debt borrowed. For banks, the interest is a component of the highest income (Dornbusch, 2004). The total revenues received by the bank, 
largely derived from the interest on the loan. Higher interest rates could lead to a high volume of people's savings. The higher the interest rate offered by banks to encourage more people to save. Economic indicators last few years seen experiencing symptoms of recovery of public confidence. The average stock price index for the last three years is at 4698.04. When viewed in detail composite stock price index for the last three years has fluctuated in 2014, the stock price index stands at 4274.18 and increased in 2015 to 5226.95. But in 2016 returned reduction to 4593.00. (www.bi.go.id). The development of share prices of mining companies registered The Indonesia Stock Exchange for the last three years 2014 to 2016 are as follows:

Table 1. Mining Company Stock Price Listed Year 2014 to 2016

\begin{tabular}{|c|c|l|c|c|c|}
\hline \multirow{2}{*}{ No. } & \multirow{2}{*}{ Issuer Code } & \multicolumn{1}{|c|}{ Company } & \multicolumn{3}{|c|}{ Year } \\
\cline { 4 - 6 } & & & 2014 & 2015 & 2016 \\
\hline 1 & ADRO & Adaro Energy Tbk & 1,090 & 1,040 & 1280 \\
\hline 2 & ANTM & Aneka Tambang (Persero) Tbk & 915.575 & 894.575 & 314 \\
\hline 3 & EARTH & Bumi Resources Tbk & 300 & 80 & 50 \\
\hline 4 & ENRG & Energi Mega Persada Tbk & 70 & 100 & 50 \\
\hline 5 & INCO & Vale Indonesia Tbk & 2,650 & 3,625 & 1,635 \\
\hline 6 & ITMG & Bayan Resources Tbk & 28,500 & 15375 & 5,725 \\
\hline 7 & MEDC & Medco Energi International Tbk & 2,100 & 3,800 & 795 \\
\hline 8 & PTBA & Coal Bukit Asam Tbk & 10,200 & 12,500 & 4,525 \\
\hline 9 & TINS & Timah (Persero) Tbk & 1599.997 & 1230 & 505 \\
\hline
\end{tabular}

Source: Indonesia Stock Exchange. Finance yahoo.com (2017)

Seen from the table above phenomenon mining company's stock price during the period the last three years has fluctuated. Even some companies experienced a significant decline in three years. PT. Bayan Resources Tbk is a company whose stock prices decline dramatically. In 2014, the price of shares of PT. Bayan Resources Tbk was in the range of Rp. 28,500 per share, the figure is the highest among other mining companies. But in the two years it decreased to Rp. 15375 per share in 2015 and continued to fall until at Rp. 5,725 per share. Likewise, several other mining companies are experiencing the same thing, not even a mining company's share price increased significantly in the last three years. CSPI is a reflection of the general capital markets activity. Increased CSPI shows the condition of the stock market is bullish, on the contrary if the decline shows the condition of the stock market is bearish.For that an investor has to understand the patterns of behavior of stock prices in the capital market. In his research, Lee (1992) has found that changes in interest rates have a significant influence on the stock price index. Meanwhile, in an article written by Moradoglu, et al. (2000), noted that research on the behavior of stock prices has been done, particularly in relation to macroeconomic variables, among them Chen et al. (1986), Geske and Roll (1983) and Fama (1965). Their results say that the stock price is affected by macroeconomic fluctuations. Some macroeconomic variables are used, among others; inflation, interest rate, exchange rate, index of industrial production, and the price of oil.

\section{LITERATURE REVIEW}

\section{Composite Stock Price Index (CSPI)}

The share price is the market value of each share of the company. Composite stock price calculation is done to determine the development of the average of all shares listed on the stock exchange. CSPI is an indicator or reflection of the overall stock price movements. Regarding the CSPI, as has been mentioned before that $\mathrm{JCI}$ is a value indicative of the overall performance of stocks in the stock market, so the CSPI in the capital market affects the stock price. The movements of stock prices are determined by the dynamics of the supply and demand. Currently in Indonesia Stock Exchange there are 11 (eleven) types of indexes, as 
follows (www.idx.co.id): (1) CSPI, (2) Sectoral Index, (3) LQ-45, (4) Jakarta Islmic Index (JII), (5) Index KOMPAS100, (6) Business Index-27 (7) Index Pefindo25, (8) Index SRI-KEHATI, (9) Index Main Board, (10) Index Development Board, and (11) Individual index.

The various types of the stock price index, in this study only uses index CSPI as the object for CSPI is a projection of the whole movement of ordinary shares and preference shares listed on the Stock Exchange. Composite Stock Price Index was first introduced on April 1, 1983. CSPI as an indicator of the movement of prices of all shares listed on the Jakarta Stock Exchange either common stock or preferred stock with a value of 100 is from 1 April 1983. Anoraga and Bannerman (2001: 100-104) simply called a price index is a number that is used to compare an event with other events. Likewise, the stock price index, the index compares the stock price changes over time. Whether the stock price declines to a certain time, stock price index measurements we need also two kinds of time, i.e. the time base and the applicable time. The time base will be used as a basis of comparison, while the valid time is the time in which the activity will be compared with the base period.

The movement of the index value will indicate changes in the market situation that occurred. Markets are skittish or transaction that is active, indicated by the index of stock prices to rise. This condition usually indicates a desired state. Steady state is indicated by the stock price index are fixed, whereas the sluggish indicated by the stock price index declined. To know the Composite Stock Price Index, used the following formula (Anoraga and Pakarti, 2001: 102):

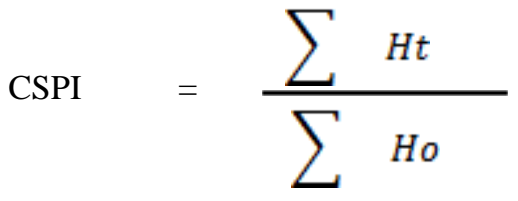

Whereas :

$\sum \mathrm{Ht}:$ The total price of all the shares at the applicable time

$\sum$ Ho : The total price of all the shares at the time basic.

CSPI is operationally expressed as the movements of prices in general of all shares listed on the Indonesia Stock Exchange on average per year from the period 2011 to 2015 are expressed in points or percent. Composite stock price calculation is done to determine the development of the average of all stocks listed on the exchange. Assessment of the company's stock performance outside the company carried out by the market through the behavior pattern of stock price movement over time. Composite Stock Price Index (Composite) is an indicator or reflection of the overall stock price movements. Regarding Stock Price Index (CSPI), as has been mentioned before that JCI is a value indicative of the overall performance of stocks in the capital market, so that JCI is in the capital market affect the stock price. In the previous study, Subiyakto (2004). found that the significant factor is the composite stock price index, the consumer goods industry index and the exchange rate of US Dollar to Indonesian Rupiah, while the sales volume of shares does not significantly influence the stock prices of the company concerned.

Hypotheses 1. Composite Stock Price Index (CSPI) is a significant effect on the stock price on selected mining companies listed on the Indonesia Stock Exchange

\section{Exchange Rate}

Foreign trade involves the use of national currencies. Foreign currency exchange rate is the price of a country's currency against the currencies of other countries. Foreign exchange rates determined in the foreign exchange market, the market where a variety of different currencies traded. If you want to exchange the national currency with other currencies, it will do so based on the prevailing exchange rate. (Samuelson, 2004: 306). Sale and purchase of foreign banknotes or banknotes known as cash foreign exchange has the properties as well as the usual cash. It is circulating in Indonesia because it was brought in by foreign businessmen. Not all banknotes can be bought and sold, depending on the foreign exchange regulations in countries of origin banknotes. The respective Banks do not always have a supply or obliged 
to always provide bank notes as banknotes should be immediately resold, because otherwise banks will lose. Exchange rates (buying and selling) sometimes because the bank may not necessarily be able to immediately resell. It depends on the state of the market where the bank is located and the type of currency paper money itself. Therefore, the selling price of paper money in some areas or even in some banks may vary (Flag Anoraga, 2004: 280).

Sale or trade foreign currency (forex) occurs because of the demand and supply. This trade occurred as a result of international economic transactions. Each import / export of goods, services or capital from one country to another will lead to the sale and purchase of foreign exchange. A transaction in foreign exchange trade consists of cash transactions, single transactions and barter transactions. The definition of cash transactions is buying and selling foreign currencies, in which the delivery traded currencies held two days after the transaction occurred. Single transactions are transactions conducted between currencies against other currencies, where the limit delivery of which is at a certain time in the future. While barter transactions is a combination of buying and selling of two currencies in cash, followed by buying and reselling the same currency in cash and stump, namely the purchase and sale of an eye against other currencies is performed in conjunction with the time limits are different (Panji Anoraga, 2004: 283).

The rupiah currency exchange rate against the US dollar in this study at an average operationalize as how much the value of the rupiah which is proportional to the value of the US dollar (USD 1) started the period 2012 to 2016, and are stated in Rupiah.

Foreign currency exchange rate is the price of one unit of money in units of another currency. Foreign exchange rates determined in the foreign exchange market, the market where a variety of different currencies traded. If you want to exchange the national currency with other currencies, sale and purchase of foreign banknotes or banknotes known as cash foreign exchange has the properties as well as the usual cash. Circulating in Indonesia it was brought by tourists or traders / foreign businessmen. Not all banknotes can be bought and sold, depending on the foreign exchange regulations in countries of origin banknotes. The respective Banks do not always have a supply or obliged to always provide bank notes as banknotes soon have to be able to immediately sell back, because otherwise banks will lose. Exchange rates (buying and selling) sometimes because the bank may not necessarily be able to immediately resell. It depends on the state of the market where the bank is located and the type of currency paper money itself. Therefore, the selling price of paper money in some areas or even in some banks may vary. the higher the exchange rate against the dollar will lead to increasingly stronger rupiah traded, so that banks will be more easy to fulfill Its obligations, so the impact on bank stock prices are rising.

Studies conducted Eugene F. Fama (1965) provides evidence that stock prices be affected by macroeconomic fluctuations. Some macroeconomic variables are used, among others; inflation, interest rate, exchange rate, index of industrial production, and the price of oil. Other researcher, Arifin (2004). proved that the factor of the rupiah against the US dollar and Stock Price Index (CSPI), which significantly affect the company's stock price the cement industry, and the inflation rate, interest rate and index of Basic Industry and Chemical (IS-IDK) not significant effect on the price company stock. Sijintak and Kurniasari (2003). Found that if the exchange rate (the exchange rate of the dollar against the rupiah) up one unit means a decline in market indicators (JCI) shares of one unit especially when the market is bearish condition. While the market is bullish, the indicators of the stock market and money market indicators together positive effect. Especially on SBI money market indicators, positive significant to affect the stockmarket.

Hypothesis 2. Exchange Rate $\left(\mathrm{X}_{2}\right)$ significantly affects the price of shares in selected mining companies listed on the Indonesia Stock Exchange.

\section{Interest Rate}

Wardane (2003) in Prawoto and Avonti (2004), the interest rate is the payment made for the use of money. The interest rate is the amount of interest to be paid per unit of time. In other words, the public must pay to borrow money opportunities. According to Samuelson and Nordhaus (1995: 197) in Wardane (2003), the interest rate is the cost to borrow money, measured in American dollars per year for every dollar borrowed. 
According to Keynes, in Wardane (2003), the interest rate is determined by the demand and supply of money (determined in the money market). Changes in interest rates, which will influence the desire to hold investments, for example in securities, where prices can go up or down depending on the interest rate (if interest rates rise, bonds fall and vice versa), so there is the possibility of holders of securities will suffer capital loss or gain. Interest rates can be divided into two, namely: (1) the nominal interest rate is the interest rate in the value of money. The rate is a value that can be read in general. Interest rates showed a number of rupiah for every single rupiah invested. (2) The real interest rate is the interest rate that has undergone a correction due to inflation and is defined as the nominal interest rate minus the inflation rate. The interest rate is expressed as a rate of return / income provided by Bank Indonesia to investors in the auction of SBI (Bank Indonesia Certificate) term of one year or commonly known as SBI one year from the period 2012 to 2016 are expressed in percent ,

Hypothesis 3. Interest Rate insignificant affect on stock price at the selected mining companies listed on the Indonesia Stock Exchange.

\section{Stock Price}

Fred and Copeland (1999: 166) in Rinati (2010) states that the stock is a sign of ownership or possession of any person or entity in a company, a share of stock is a piece of paper stating that the owner of the paper is its owner (any portion or quantity) of a company that is published a paper (stock). According to Samson (2006: 45) that the stock is proof of having a company where the owner is also known as shareholders(shareholder or stockholder).A person or a party is said to be valid if shareholders in the Shareholder Register (DPS) or if the party is registered as a shareholder. As for the types of stocks according to Halim and Sarwoko (2010: 13) are: Preferred Stock and the Common Shares. In this study, price share expressed as a yearly closing stock price of government and private banks began to cover the period 2011 to 2015 are expressed in Rupiah. The interest rate is the amount of money paid in return for the use of borrowed debt which has been established by Bank Indonesia. The interest rate on the loan repayment rate or other investments is on top of the repayment agreement, which is expressed in a percentage of the bank loan. For banks, the interest is a component of the highest income. The total revenues received by the bank, largely derived from the interest on the loan. Higher interest rates could lead to a high volume of people's savings. The higher the interest rate offered by banks to encourage more people to save money, which means that people tend to reduce their consumption in order to increase savings balances held.

In addition, higher interest rates will impact the soaring cost of capital of the company, so the company will have competition in the investment, meaning that investors tend to prefer investing into money markets on savings compared to the capital market. Instead of low interest rates, both lending rates and deposit rates will impact decreasing people's desire to save money, while for this condition is very advantageous because the company can take credit to raise capital or investments with a lower interest rate. Studies conducted Bong-So Lee (1992) found that a change in interest rates has a significant influence on the stock price index. Wiyani et al. (2005) found that trading volume has absolutely no effect on stock prices but the exchange rate and interest rates on deposits both partially and simultaneously influence the stock price banking companies listed in Indonesian Stock Exchange. Sugeng and Mulyono (2000) proved that earning per share positive and significant impact on stock prices. While the variable interest rate negative effect on stock prices.

Hypothesis 4. Composite Stock Price Index, Rupiah Exchange Rate and Interest Rate as a simultaneously and positive effect on elected Mining Company Stock Price listed on the Indonesia Stock Exchange

\section{Methods}

This study used quantitative approach. A quantitative approach by Arikunto (2006: 12), much is required to use numbers, ranging from data collection, interpretation of data and results. In addition to quantitative research is also no data in the form of qualitative information. Research will be conducted in Gorontalo through the Exchange Information Center Corner and Internet access through multiple sites, namely: www.idx.co.id (site of the Indonesia Stock Exchange, www.bi.go.id, Indonesia Banking and www.infobank.co.id). The study is planned for two months, i.e. April to July 2017. 
Data collection methods used in this study is collecting secondary data, data that has been finished and published by the Information Center Corner Exchange and Bank Indonesia (BI) in Gorontalo. In addition, researchers also access the internet, through sites www.idx.co.id and www.bi.go.id Total population in this study were as many as 41 public mining companies listed on the Go Indonesia Stock Exchange. The sampling technique is done through method purposive sampling with the purpose to obtain a sample that is consistent with the objectives Research. Purposive sampling a sampling method based on several considerations or criteria. Criteria stocks that will do the research for the research sample is as follows Poncho (2008): The mining company publicly listed in the Indonesia Stock Exchange (BEI) in the period of the study is 2016; it has a complete data associated with variables used in the study. The Mining companies in the index Compass 100 from January to December 2016.

Table 2: Criteria of Sample Selection

\begin{tabular}{|c|l|c|}
\hline No. & \multicolumn{1}{|c|}{ Criteria } & Number \\
\hline 1 & mining company listed on the Indonesia Stock Exchange in 2015 & 41 \\
\hline 2 & $\begin{array}{l}\text { Companies do not publish financial statements in a row during the period of observation. } \\
\text { banking company listed in Indonesia Stock Exchange and in accordance with the } \\
\text { characteristics of the sample Criteria }\end{array}$ & 32 \\
\hline
\end{tabular}

Based on these criteria, the number of samples used in this study is 9 companies. The sample in this study can be seen in the following table:

Table 3: Sample

\begin{tabular}{|c|c|c|}
\hline No & Code & Company \\
\hline 1 & ADRO & Adaro Energy Tbk \\
\hline 2 & ANTM & Aneka Tambang (Persero) Tbk \\
\hline 3 & EARTH & Energi Mega Persada Tbk \\
\hline 4 & ENRG & Vale Indonesia Tbk \\
\hline 5 & INCO & Bayan Resources Tbk \\
\hline 6 & ITMG & Coal Bukit Asam Tbk \\
\hline 7 & MEDC & Timah (Persero) Tbk \\
\hline 8 & PTBA & \\
\hline 9 & TINS & \\
\hline
\end{tabular}

The number of samples in this study did not meet the minimum requirement of the number of data observations minimal i.e. $\mathrm{n}=30$, then processing the data using time series, So that the amount of data to be processed is obtained by multiplying the number of companies which is 9 to 36 month observation period (January 2014 to December 2016). So the number of observations is 324 data. The analytical tool used in this study is multiple linear regression analysis with the following formula:

$\mathrm{Y}=\mathrm{b}_{o}+\mathrm{b}_{1} \mathrm{X}_{1}+\mathrm{b}_{2} \mathrm{X}_{2}+\mathrm{b}_{3} \mathrm{X}_{3}+\mathrm{C}$

Where;

$$
\begin{array}{ll}
\mathrm{Y} & =\text { the stock price } \\
\mathrm{b}_{\mathrm{o}} & =\text { Constant /intercept } \\
\mathrm{b}_{1}-\mathrm{b}_{3} & =\text { parameter / coefficient to be estimated }
\end{array}
$$




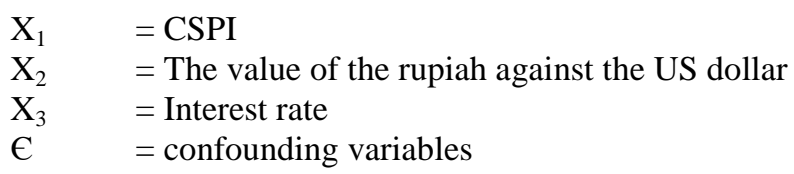

Utilization of regression in practice using Classical Assumption Test (Sunyoto (2011: 79) Testing classical assumption shared by the normality test, multicollinearity, autocorrelation, heteroscedasticity:

\section{Descriptive Statistics}

In this research, there are four variables will be analyzed, namely the three independent variables and the dependent variable. The independent variable in this study is the Composite Stock Price Index (CSPI), Exchange rate and Interest rate, while the dependent variable is the stock price. The data used in this research is secondary data in the form of monthly data for the period January 2013 to December 2015 were published in a stock exchange Indonesia (www.idx.co.id), Bank Indonesia (www.bi.go.id) and other internet sites that load research data is needed.

Using of combination panel data and cross section, time series where units of cross section the same measured at different times. So in other words, panel data is the same data from several individuals were observed within a certain time. If we have a $\mathrm{T}$ period of time $(\mathrm{t}=1,2, \mathrm{~T})$ and $\mathrm{N}$ number of individuals $(\mathrm{i}=$ $1,2, \ldots, \mathrm{N})$, then the panel data we will have a total of as much as NT observation unit. The advantages of panel data is able to provide more data that will produce a degree of freedom (df) is greater (degrees of freedom), but it can solve problems that arise when there is a problem removal variable. By using the method Data panel than 9 companies sampled is then multiplied by the study period ( 36 months) so that the sample into the data $108(9 \times 36=108)$. The following SPSS output of each of the variables studied for the minimum, maximum, mean and standard deviation:

Research Findings show that the amount of data used in this study as many as 324 data samples. The average of the variable value of monthly stock price over the three years is USD. 4473.1982 per share with an average rate of deviation of $7776.36331 \%$. Value priced the highest monthly share is Rp. 41450.00 per share while the lowest value is Rp. 50.00 per share. Standard deviation exceeds the average value of stock prices to the level of $1.73843 \%$ variation coefficient obtained from the show fluctuations in the price variable data shares during the observation period.

Value Composite Stock Price Index (minimum) is Rp. 4195.09 with the highest score (maximum) is Rp. 5518.67. In addition to the composite stock price index shows average values (mean) of Rp.4.806, 3054 with a standard deviation value of $358.07173 \%$. By looking at the standard deviation value which is smaller than the average, this indicates that the data used in the variable interest rate has a small distribution data with coefficient of variation of $0.00745 \%$.

For variable Exchange Rate, the lowest value (minimum) in a monthly period is Rp. 10186.65 per 1 US dollar and the highest (maximum) is Rp. 14896.10. In addition Rupiah exchange rate variable indicates the average value of Rp. 12405.7264 with a standard deviation of $1341.87963 \%$. The coefficient of variation of the rupiah in $0,108166 \%$. This indicates that the data on Rupiah exchange rate variable has a distribution that is small, because the standard deviation is smaller than the average value. It can be concluded that the distribution of data on variables rupiah was pretty good. The mean value of the variable interest rates is $7.1736 \%$, with the highest value of $7.75 \%$ and the lowest rate of $5.75 \%$. The standard deviation of the interest rate is on 0,65138 smaller than the mean value of the coefficient of variation of $0.09080 \%$. Thus it can be said that the data on the variable interest rate has a small distribution data.

\section{Results}

Processing data in this study using SPSS ver. 14 then generates this study as follows:

\section{Classical Assumption Test}

1. Normality Test Data

To determine whether or not normal distribution of data on normality test can be done by using the graph Normal PP Plot and Kolmogorov-Smirnov test. In the picture above shows that the data are 
not normally distributed with no spread of the data around diagonal lines or some data away from diagonal lines is reinforced with Kolmogorov-Smirnov test where the test One Sample KolmogorovSmirnov test using unstandardized residual value. The same result that the data are not normally distributed. It looks at the significant value of the variable Index is 0.003, 0.000 Exchange Rate, Interest Rate of 0.000 and 0.000 Stock Price variable in which the whole is less than 0.05 . To normalize the data, the data in the transformation into the form Ln, then performed a linear regression test back, the rainy results indicate that the data have normal distribution; the normal graph PP-plot shows the data spread around the diagonal line.

2. Multicolinearity test.

Multicolinearity test is performed to determine whether there is a correlation between independent variables. Based on the above results the SPSS output, it appears that the magnitude of the VIF at variable Composite Stock Price Index has VIF 1,003 or $\rho<10$, variable Exchange Rate VIF worth 3,287 or $\rho<10$ and a variable rate of interest worth VIF 3,290 or $\rho<10$. The value of tolerance on the third variable worth $\rho>0.1$. Results VIF and tolerance in this study showed there was no correlation multicollinearity in variables independent and qualify for the multiple regression models.

3. Heteroskedasticity test

Good regression equation is if there homoscedasticity where the scatterplot of the data processing between ZPRED and SRESID spread below or above the point 0 on the $\mathrm{Y}$ axis and does not have a regular pattern. Based on the picture scatterplot below can be concluded that the data spread out and do not form a particular pattern that does not happen heteroskedasticity

\section{Linear Regression}

Linear Regression is used to calculate the direction and magnitude of the influence of the variables independent (Composite Stock Price Index, Exchange Rate and Interest Rate) the variable dependent (stock price) mining company listed on the Indonesia Stock Exchange. For processing data in this study using SPSS14. Based on the results, it can be arranged multiple linear regression equation is as follows: $\mathbf{Y}=$ $43,772+0,717 \mathrm{X} 1-5,116 \times 2+3,077 \mathrm{X} 3$ From the multiple linear regression equation is known that the constant value of 43.772 means that if the value of the variable Composite Stock Price Index, Exchange Rate and Interest Rate equal to zero, then the stock price is worth 43.772.

Composite Stock Price Index has a coefficient of 0.717, which means if variable Composite Stock Price Index increased by 1 point then the stock price will increase by 0.717 units, assuming other variables held constant, and this suggests a positive relationship (unidirectional). Variable Exchange Rate has a coefficient of -5.166, which means if variable Exchange Rate increased by one unit then the stock price will rise by -5.166 unit assuming other variables held constant, and this suggests a negative relationship (opposite). The variable interest rate has the coefficient value of 3.077 which means if variable interest rates increased by one unit then the stock price will increase by 3.077 units, assuming other variables held constant, and this suggests a positive relationship (unidirectional).

\section{Hypothesis testing}

T-test is a useful statistical test to determine the effect of each independent variable partial to the stock price. The table shows the coefficient of value of each variable

1. CSPI on stock price value $t_{-}$statistic on Log_Indeks amounted to 0.585 with significant value 0,559 , for a value of $\mathrm{t}_{\text {table }}$ in the Composite Stock Price Index $(\alpha=0.05 ; \mathrm{df}=\mathrm{n}-2)$ is equal to 1,967 meaning that $\mathrm{t}_{\text {-statistic }}<\mathrm{t}_{\text {-table }}(0.585<1.967)$. Thus the results show that the hypothesis is rejected.

2. Exchange Rate on stock price. The value of t-statistic exchange rate of -3.433 with a significant value of 0.001 while $\mathrm{t}_{\text {table }}$ variable Exchange Rate $(\alpha=0.05$; $\mathrm{df}=\mathrm{n}-2)$ is equal to 1,967 meaning that $\mathrm{t}$ statistic $>\mathrm{t}_{\text {table }}(-3.433>1.967)$. These results indicate that the hypothesis is accepted.

3. Interest Rate on Stock Price. The value of interest rates of 1.817 with a significant value of 0.070 , while the value of $\mathrm{t}_{\text {table }}$ interest rate $(\alpha=0.05 ; \mathrm{df}=\mathrm{n}-2)$ is equal to 1,967 meaning $_{\mathrm{t}} \mathrm{t}_{\text {-statistic }}>\mathrm{t}_{\text {-table }}$ $(1.817>1.967)$, These results indicate that the hypothesis is rejected.

4. Fisher's test. F test is done to see if all the independent variables have a significant influence on the dependent variable. Based on the results above show that SPSS statistical test value of $\mathrm{f}_{\text {-count }}$ equal to 5,278 with significant values of $0001<0,05$. While $\mathrm{f}_{\text {table }}$ obtained 2,633 where $\mathrm{df} 1=2(\mathrm{k}-1)$ and $\mathrm{df} 2$ $=322(\mathrm{n}-\mathrm{k})$ with a significant level of 0:05. Therefore $\mathrm{f}_{\text {-count }}>\mathrm{f}_{\text {table }}$ or $5.278>2.633$. These results indicate that the hypothesis is accepted. 
5. Determination. The coefficient of determination is used to determine how much the independent variables affect the dependent variable. Results SPSS 14 showed that the coefficient of determination for the three independent variables obtained figures adjusted R-square of 0,038 meaning that the variable CSPI, Exchange Rate and Interest Rate contributing effect on stock price 3.80\% while the remaining $96.2 \%$ influenced by other factors beyond the variables used in this study.

Based on the results of multiple linear regression analysis either simultaneously or partially Composite Stock Price Index, Exchange Rate and Interest Rate significantly influence the elected Mining Company Stock Price listed on the Indonesia Stock Exchange. The influence of each independent variable on the dependent variable is as follows:

1. Effect of Stock Price Index on stock Price Hypothesis Based on the partial test results showing that stock price index and no significant positive effect on the stock price changes. These findings support the theory that the stock price calculation is done to determine the development of the average of all stocks listed on the exchange. Composite Stock Price Index (Composite) is an indicator or reflection of the overall stock price movements. Regarding Stock Price Index (CSPI), as has been mentioned before that JCI is a value indicative of the overall performance of stocks in the capital market, so that JCI is in the capital market affect the stock price.

2. Effect of Exchange Rate on Stock Price Based on the results showed that the Exchange Rate is partially a significant negative effect on the stock price changes. A negative value in the variable Exchange Rate indicates the weakening rupiah against the US dollar from year to year. Increasingly low value of the rupiah against the dollar would cause the weaker rupiah traded, so that the bank's liabilities in foreign currency will be higher. Thus, banks will be increasingly difficult to meet its obligations, so the impacts on bank stock prices are low. Conversely, the higher the exchange rate against the dollar will lead to increasingly stronger rupiah traded, so that banks will be more easy to fulfill Its obligations, so the impact on bank stock prices are rising. Exchange rate has a close relationship with the movement of stock prices. For investor depreciation of the rupiah against the dollar indicates that Indonesia's economic outlook bleak. For the depreciation of the rupiah may occur if the fundamental factor of the Indonesian economy is not strong (Sunariyah, 2006). It certainly adds to the risk for investors if they want to invest in the stock market of Indonesia. With the value of the rupiah which depreciate will cause production costs borne by the company will go up so it would depress corporate profits. If the increase in raw material costs could not be followed by an increase in selling their production of the profits generated will be reduced, meaning a company's financial risk increases, increasing the risk of the company would affect the view of the investors. Additionally investors will tend to prefer to hold assets like the dollar whose value is more profitable than stock in a country that values its currency weaker. Investors are likely to sell its stake and switch in assets such as foreign currencies. The sell-off by investors who will push down stock prices that impact on the decrease in the stock price index IDX.

3. Interest rates on stock prices. Based on the results showed that the rate of interest partially and not significant positive effect on stock price changes. Currently, Indonesian Bank uses interest rate BI as an instrument to control inflation. If inflation is perceived to be quite high, Bank Indonesia to raise the $\mathrm{BI}$ rate to curb rising inflation. BI rate changes will give effect to the capital market and the financial markets. If the BI rate rise, will directly increase the interest burden. Companies that have leverage high will get a very severe impact on the increase of the interest rate. BI rate hike could reduce the profitability of the company so as to give effect to the stock price of the company concerned.

4. These findings indicate that higher interest rates will impact the soaring cost of capital of the company, so the company will have competition in the investment, meaning that investors tend to prefer investing into money markets on savings compared to the capital market. Instead of low interest rates, both lending rates and deposit rates will impact decreasing people's desire to save money, while for this condition is very advantageous because the company can take credit to raise capital or investments with a lower interest rate.

\section{Conclusion}

Partially Exchange Rate negative and significant effect on stock price of selected mining companies listed on the Indonesia Stock Exchange. Meanwhile Partially CSPI and Interest Rate positive and insignificant effect on stock price of selected mining companies listed on the Indonesia Stock 
Exchange. CSPI, Exchange Rate and Interest Rate simultaneously have a positive and significant effect on stock prices of mining companies selected are listed in the Indonesia Stock Exchange. There is a huge influence of other factors outside variables raised on stock prices of mining companies selected are listed in the Indonesia Stock Exchange.

The study recommends that those companies or shareholders should pay attention to macro factors, especially Exchange Rate as a reference to predict stock prices because these variables have the most significant effect on stock prices of mining companies. For investors can consider three variables Composite Stock Price Index, Exchange Rate and Interest Rate were simultaneously positive and significant effect on stock prices as a basis for assessing and selecting stocks of companies which are profitable. To advanced researchers should conduct research using different variables with the study variables and the observation period were more numerous and real.

\section{References}

[1] Arifin, (2004). Factors That Influence on Stock Price Cement Industry Companies that go public on the Jakarta Stock Exchange (JSX).

[2] Fama, Eugene, (1965). The Behavior of Stock MarketPrices. Journal of Business, Volume 38, Issue 1 (Jan, 1965), 34-105.

[3] Husnan Suad, (2005), Basics Securities Portfolio Theory and Analysis, Fourth Edition, UUP STIM YKPN, Yogyakarta.

[4] Sitinjak, ELM and Kurniasari, W. (2003). Indicators Stock Market and Money Market Mutual Relating Judging from the Stock Market was Bullish and Bearish. Journal of Economic Research and Management, 3 (3).

[5] Lee, SB. (1992). Causal Relations Among Stock Return, Interest Rate, Real Activity, andInflation.Journal of Finance, 47: 1591-1603.

[6] Prastiyaningtyas, Fitriani. (2010). Factors Affecting Banking Profitability (Study On The Public UmumGo Bank Listed in Indonesia Stock Exchange Year2005-2008).Skripsi.Fakultas Economics. Diponegoro University.

[7] Rinati, Ina, (2009). Influence Net Profit Margin (NPM), Return on Assets (ROA) and Return on Equity (ROE) Share Price Company Listed On LQ 45. Within a Scientific Journal of Gunadarma University.

[8] Samsul, Mohammad, (2006). Capital Markets and Portfolio Management, Erland, Surabaya.

[9] Siamat, Dahlan. (2002). Management of Financial Institutions: PT. Gramedia Pustaka Utama.

[10] Soerjono Soekanto, (1969) an introductory sociology, PT. King Grafindo Persada, Jakarta

[11] Sugeng and Mulyono. (2000). Influence Earning Per Share (EPS) and Interest Rate Share Price in the Jakarta StockExchange.Journal of Economics and Management. Vol 1. No. 2. Graduate University of Gajayana. Poor.

[12] Sugiyono, (2012). Understanding QualitativeResearch.Bandung. Alfabeta.

[13] Republic of Indonesia. (1998). Law No. 10 Year on Banking

[14] Wiyani, W., \& Vitello, A. (2005). Effect of Exchange Rate, Interest Rate Deposit and Shares Trading Volume on stock price. Journal of Banking and Finance, 9 (3), 884-903. 